\title{
Distribution and treatment of harmful gas from heavy oil production in the Liaohe Oilfield, Northeast China
}

\author{
Zhu Guangyou ${ }^{1,2 *}$, Zhang Shuichang ${ }^{1,2}$, Liu Qicheng ${ }^{3}$, Zhang Jingyan', Yang \\ Junyin $^{3}$, Wu Tuo ${ }^{3}$, Huang $\mathrm{Yi}^{3}$ and Meng Shucui ${ }^{1}$ \\ ${ }^{1}$ Research Institute of Petroleum Exploration and Development, PetroChina, Beijing 100083, China; \\ ${ }^{2}$ State Key Laboratory of Enhanced Oil Recovery, Research Institute of Petroleum Exploration and Development, \\ PetroChina, Beijing 100083, China; \\ ${ }^{3}$ Research Institute of Exploration and Development, PetroChina Liaohe Oilfield Company, Panjin, Liaoning 124010, China \\ (C) China University of Petroleum (Beijing) and Springer-Verlag Berlin Heidelberg 2010
}

\begin{abstract}
The distribution and treatment of harmful gas $\left(\mathrm{H}_{2} \mathrm{~S}\right)$ in the Liaohe Oilfield, Northeast China, were investigated in this study. It was found that abundant toxic gas $\left(\mathrm{H}_{2} \mathrm{~S}\right)$ is generated in thermal recovery of heavy oil. The $\mathrm{H}_{2} \mathrm{~S}$ gas is mainly formed during thermochemical sulfate reduction (TSR) occurring in oil reservoirs or the thermal decomposition of sulfocompounds (TDS) in crude oil. $\mathrm{H}_{2} \mathrm{~S}$ generation is controlled by thermal recovery time, temperature and the injected chemical compounds. The quantity of $\mathrm{SO}_{4}{ }^{2-}$ in the injected compounds is the most influencing factor for the rate of TSR reaction. Therefore, for prevention of $\mathrm{H}_{2} \mathrm{~S}$ formation, periodic and effective monitoring should be undertaken and adequate $\mathrm{H}_{2} \mathrm{~S}$ absorbent should also be provided during thermal recovery of heavy oil. The result suggests that great efforts should be made to reduce the $\mathrm{SO}_{4}^{2-}$ source in heavy oil recovery, so as to restrain $\mathrm{H}_{2} \mathrm{~S}$ generation in reservoirs. In situ burning or desulfurizer adsorption are suggested to reduce $\mathrm{H}_{2} \mathrm{~S}$ levels. Prediction and prevention of $\mathrm{H}_{2} \mathrm{~S}$ are important in heavy oil production. This will minimize environmental and human health risks, as well as equipment corrosion.
\end{abstract}

Key words: Toxic gas, $\mathrm{H}_{2} \mathrm{~S}$, heavy oil production, TSR, Liaohe Oilfield

\section{Introduction}

As a highly toxic and corrosive gas, $\mathrm{H}_{2} \mathrm{~S}$ is an important safety concern in production because it can cause great damage to the surroundings and human beings (Orr, 1977; Machel et al, 1995; Krouse et al, 1988; Worden et al, 1995; Dai et al, 2004; Zhu et al, 2005a). A concentration of $\mathrm{H}_{2} \mathrm{~S}$ lower than 0.2-0.3 ppm is safe for human beings. There will be a strong smell when at 20-30 ppm. Olfactory paralysis will occur when its concentration is $100-150 \mathrm{ppm}$. People can die within a couple of seconds when the $\mathrm{H}_{2} \mathrm{~S}$ concentration is $1000 \mathrm{ppm}$. The $\mathrm{H}_{2} \mathrm{~S}$ concentration must be less than $1 \mathrm{ppm}$ according to the national standard of China (GBZ 2-2002). In most blocks in the heavy oil steam drive areas of the Liaohe oilfield, the concentration of $\mathrm{H}_{2} \mathrm{~S}$ in natural gas is more than $200 \mathrm{ppm}$. This level is dangerous for people.

During the oil exploration and development processes in China, there have been more than 10 major accidents from $\mathrm{H}_{2} \mathrm{~S}$ toxicity, resulting in great casualties and property loss.

*Corresponding author. email: zhuguangyou@petrochina.com.cn; Received July 31, 2009
Therefore, the concentration of $\mathrm{H}_{2} \mathrm{~S}$ gas has been monitored since these accidents happened. It has been reported that large amounts of $\mathrm{H}_{2} \mathrm{~S}$ is generated during heavy oil thermal recovery process (Aplin et al, 1995; Wilhelm, 1981; Lamoureux-Var and Lorant, 2005). It is a new problem, first found in the Liaohe Oilfield, in the thermal recovery process in China.

The Liaohe Oilfield is the third largest oilfield in China, and also the largest production base of heavy oil and extraheavy oil in China. Development of the heavy oil resource and its enhanced oil recovery (EOR) is the focus for the recent exploration and development of the Liaohe Oilfield. As a main method in the early development stages of Liaohe oilfield, steam soak has a history for more than 20 years, and the rate of crude oil production declines with the steam soak times. As a follow-up method, steam drive was first applied in Gaosheng area in 1998, and then was applied in the Qi 40, Wa 38 and other pilot areas in the Liaohe Oilfield. In recent years, toxic gas, mainly $\mathrm{H}_{2} \mathrm{~S}$, has been found in many pilot areas, especially, with a higher concentration in the steam drive areas. For example, the concentration is up to $4.49 \%$ in well Wa-3730 of Wa-38 block in the Xiaowa area, and up to $3.27 \%$ in well Qi 40-9-025 in Qi 40 block. And gas with low 
$\mathrm{H}_{2} \mathrm{~S}$ content has also been found in other thermal recovery pilot areas, oil and gas gathering equipment and transportation pipelines, and multi-function stations.

\section{Generation of $\mathrm{H}_{2} \mathrm{~S}$ in thermal recovery pilot areas of heavy oil in the Liaohe Oilfield}

$\mathrm{H}_{2} \mathrm{~S}$ was first found in gas in the late 1990s during the steam drive process in Gao 3 block of Gaosheng Oilfield in the western depression of the Liaohe Oilfield. The content of $\mathrm{H}_{2} \mathrm{~S}$ is between $0.41 \%$ and $0.95 \%$. In recent years, $\mathrm{H}_{2} \mathrm{~S}$ has been found in the Qi 40 and Wa 38 blocks (seen in Fig. 1). Besides, low content $\mathrm{H}_{2} \mathrm{~S}$ has also been found in some steam soak areas. Judging from the current $\mathrm{H}_{2} \mathrm{~S}$ distribution, it is mainly located in the heavy oil areas in the western depression of the Liaohe Oilfield, particularly in the steam drive areas.

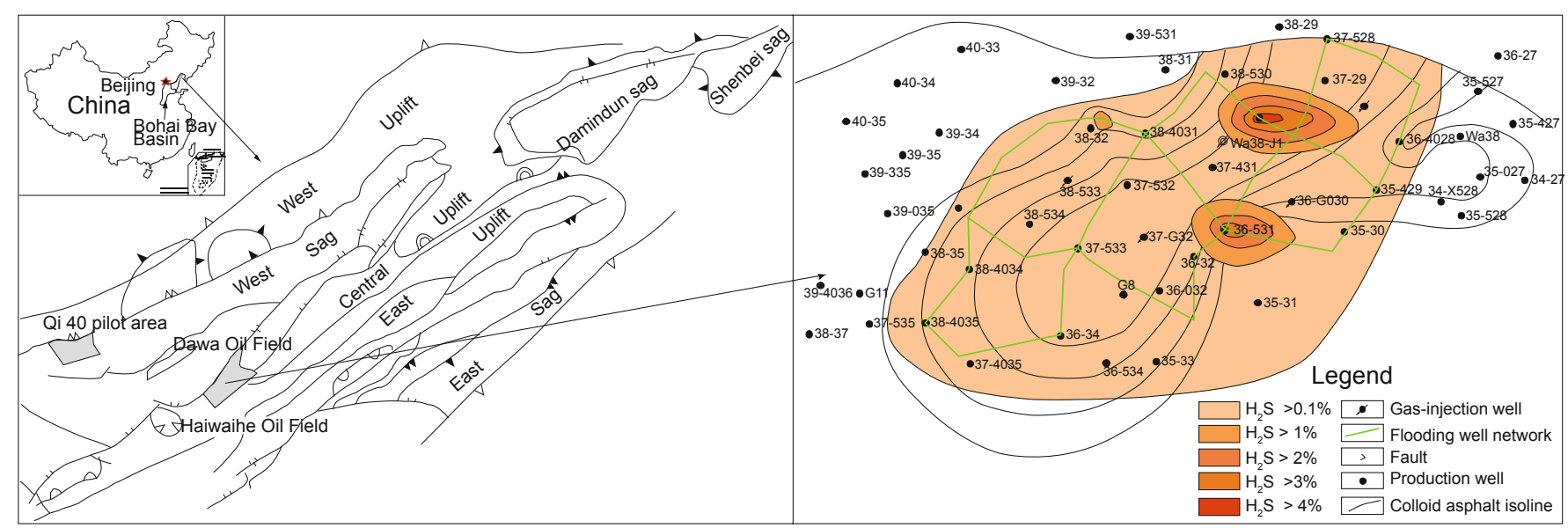

Fig. 1 Distribution relationship between hydrogen sulfide and colloid \& asphaltum in the Wa 38 block, Liaohe Oilfield

Judging from the $\mathrm{H}_{2} \mathrm{~S}$ distribution, nearly all the $\mathrm{H}_{2} \mathrm{~S}$ was formed during the thermal recovery process, so it is of secondary origin. Therefore, we could use the exclusive method to make a preliminary determination. $\mathrm{H}_{2} \mathrm{~S}$ formed from bacterial sulfate reduction (BSR) has a wide range of distribution (Machel, 2001), however, this kind of $\mathrm{H}_{2} \mathrm{~S}$ containing gas has some distinctive characteristics: First, $\mathrm{H}_{2} \mathrm{~S}$ content is low; Second, the reservoir conditions have to be suitable for micro-organisms to live, especially the temperature. It is known that the maximum temperature for most micro-organisms is about $80^{\circ} \mathrm{C}$, that is, if the temperature is higher than $80^{\circ} \mathrm{C}$, all the micro-organisms, especially the sulfate-reducing bacteria, will die. Under normal conditions, the most appropriate temperature for sulfate-reducing bacteria to live is about $34{ }^{\circ} \mathrm{C}$. The reservoir temperature in thermal recovery pilot areas of Liaohe heavy oil is above $80{ }^{\circ} \mathrm{C}$, which is higher than tolerated by sulfatereducing bacteria, so we can exclude biogenic $\mathrm{H}_{2} \mathrm{~S}$ as a source for the $\mathrm{H}_{2} \mathrm{~S}$ in this area.

Sulfur-bearing organic material occurs in oil and gas reservoirs, for example, in source rocks and crude oil. The organic matter mainly exists in crude oil in Liaohe heavy oil province, and the sulfur content is between $0.1 \%$ and $0.4 \%$ (low-sulfur crude oil). When sulfur compounds are heated, heterocyclic sulfur cracks and $\mathrm{H}_{2} \mathrm{~S}$ is formed, that is, thermal decomposition of organic matter. However, $\mathrm{H}_{2} \mathrm{~S}$ formed in this way could not reach high content. The low $\mathrm{H}_{2} \mathrm{~S}$ content is likely to be related to thermal decomposition of the sulfurbearing organic compunds.

For $\mathrm{H}_{2} \mathrm{~S}$ formation, gypsum or other sulfate minerals, hydrocarbons and high-temperature conditions are required for TSR (Zhu et al, 2005b; 2007; Mougin et al, 2007). The thermal recovery temperature in the heavy oil reservoirs of the Liaohe Oilfield is higher than $120{ }^{\circ} \mathrm{C}$, suitable for TSR. However, no significant gypsum is found in the Shahejie formation, so many scholars have questioned the causes of TSR (Zhang et al, 2005; Zhu et al, 2005b). In fact, when TSR occurs, it is the thermal chemical reaction between crude oil and $\mathrm{SO}_{4}^{2-}$ rather than the reaction between crude oil and gypsum, that is to say, a certain concentration of $\mathrm{SO}_{4}{ }^{2-}$ in the formation water is required. The investigation in this paper shows that the high $\mathrm{SO}_{4}{ }^{2-}$ content, usually hundreds of parts of per million, in the formation water of the Liaohe oilfield is the basis for TSR to produce $\mathrm{H}_{2} \mathrm{~S}$.

Previous research ( $\mathrm{Zhu}$ et al, 2009) shows that $\mathrm{H}_{2} \mathrm{~S}$ is mainly generated from the TSR (thermochemical sulfate reduction, i.e. hydrocarbon and sulfate ions react chemically) and from the thermal decomposition of sulfocompounds (TDS) within oil in heavy oil pilot areas of the Liaohe Oilfield. Although hydrothermal cracking of heavy oil can produce $\mathrm{H}_{2} \mathrm{~S}$ with a wide range of distribution during the stream drive process, the $\mathrm{H}_{2} \mathrm{~S}$ content is usually low. Sulfate required for TSR comes partly from the chemical reagent injected into the reservoirs before and after the thermal recovery and partly from high levels in the formation water in the third section of Shahejie formation. The thermal recovery temperature is also suitable for TSR, so TSR is probably taking place in the reservoir. Besides, because of the poor thermal stability of some injected chemical reagents (such as sulfonate), $\mathrm{H}_{2} \mathrm{~S}$ can be formed by their thermal decomposition during the steam drive process. 


\section{$3 \mathrm{H}_{2} \mathrm{~S}$ distribution in the thermal recovery pilot areas of heavy oil in Liaohe Oilfield}

The data analysis on the $\mathrm{H}_{2} \mathrm{~S}$-containing gas made by the Institute of Oilfield Test Center and the Huanxiling oil production plant, Liaohe Oilfield, shows that $\mathrm{H}_{2} \mathrm{~S}$ distribution is wider in heavy oil pilot areas than in light oil pilot areas. In the heavy oil pilot areas, wells with high $\mathrm{H}_{2} \mathrm{~S}$ content are all in the steam drive areas (Fig. 2). In the Qi 40 block, there are 110 wells with $\mathrm{H}_{2} \mathrm{~S}$ content above $200 \mathrm{mg} / \mathrm{m}^{3}$, accounting for about one-third of the total wells. Though the total horizontal $\mathrm{H}_{2} \mathrm{~S}$ distribution is not very clear, the wells in the central Qi 40 steam drive area all have a high $\mathrm{H}_{2} \mathrm{~S}$ content, indicating that high-temperature steam drive may be favorable to $\mathrm{H}_{2} \mathrm{~S}$ generation, and the high-temperature is likely to be an important factor for high $\mathrm{H}_{2} \mathrm{~S}$ concentration.

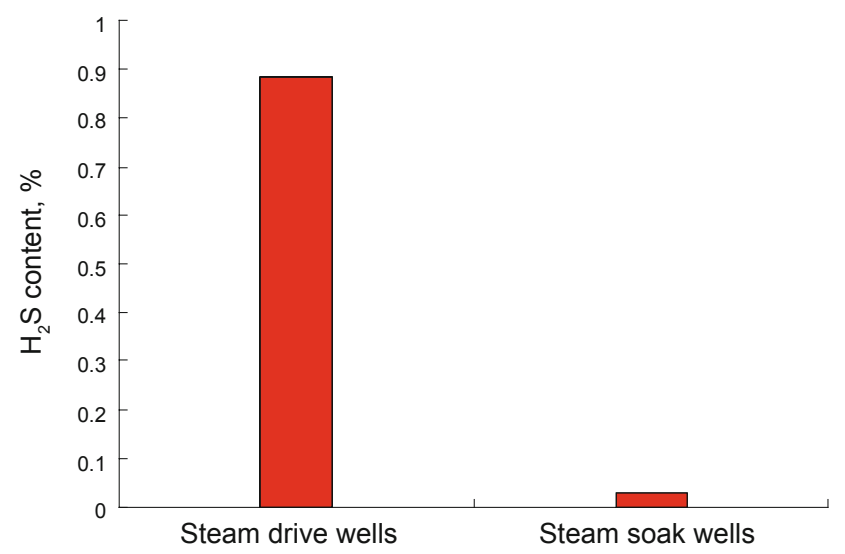

Fig. 2 Comparison of $\mathrm{H}_{2} \mathrm{~S}$ contents between steam drive wells and steam soak wells

\section{Relationship between $\mathrm{H}_{2} \mathrm{~S}$ content and recovery time and mode}

Based on the $\mathrm{H}_{2} \mathrm{~S}$ distribution in each area (seen in Fig. 1), the distribution of $\mathrm{H}_{2} \mathrm{~S}$ is wider in the stream soak pilot area than in the stream drive area. However, the $\mathrm{H}_{2} \mathrm{~S}$ content is higher in the stream drive area than in the steam soak area, indicating that $\mathrm{H}_{2} \mathrm{~S}$ generation is related to the mode of thermal recovery.

In the thermal recovery pilot areas of heavy oil in the Liaohe Oilfield, the area of high $\mathrm{H}_{2} \mathrm{~S}$ content often locates in the pilot test area in comparison to the expanded pilot area. Two areas of the Qi 40 block are now in the steam drive stage, and different steam drive durations have led to different $\mathrm{H}_{2} \mathrm{~S}$ concentrations. In general, the $\mathrm{H}_{2} \mathrm{~S}$ content is higher in the pilot test area than in the expanded pilot area. The high $\mathrm{H}_{2} \mathrm{~S}$ content also appears in the pilot test area and its peripheral areas.

Table 1 shows the test result of $\mathrm{H}_{2} \mathrm{~S}$ for well Qi 409-028, monitored by the Institute of Oilfield Test Center, Liaohe Oilfield, in the expanded test area. It is seen that the $\mathrm{H}_{2} \mathrm{~S}$ content was up to $0.79 \%$ and fluctuated during the development process, which might be related to the EOR operations.
Table 1 Changes in $\mathrm{H}_{2} \mathrm{~S}$ content for Qi 40-9-028 well in steam drive pilot area

\begin{tabular}{cccc}
\hline $\begin{array}{c}\text { Monitoring } \\
\text { frequency }\end{array}$ & $\begin{array}{c}\mathrm{H}_{2} \mathrm{~S} \\
\mathrm{v} / \mathrm{v}, \%\end{array}$ & $\begin{array}{c}\mathrm{H}_{2} \mathrm{~S} \\
\mathrm{mg} / \mathrm{m}^{3}\end{array}$ & Monitoring date \\
\hline 1 & 0.2779 & 3986 & $2005-11-05$ \\
2 & 0.7389 & 10599 & $2006-03-23$ \\
3 & 0.7448 & 10683 & $2006-03-24$ \\
4 & 0.6306 & 9045 & $2006-06-06$ \\
5 & 0.7893 & 11321 & $2006-08-21$ \\
6 & 0.2352 & 3374 & $2006-11-02$ \\
7 & 1.2162 & 17445 & $2006-12-05$ \\
\hline
\end{tabular}

The results of the seven tests are not stable, with an upward trend. In November 2005 , the measured $\mathrm{H}_{2} \mathrm{~S}$ concentration was $0.2779 \%$, and after profile control, on December 5, 2006 it was up to $1.2162 \%$. As the profile control increased the spread of injected steam, some operations in the production process, such as steam-soak after steam injection, profile control and viscosity reduction, would be favorable to increase the concentration of $\mathrm{H}_{2} \mathrm{~S}$. Based on the monitoring of the gas in the wells, it is found that the concentration of $\mathrm{H}_{2} \mathrm{~S}$ increased in the expanded pilot area along with the time of extended steam drive. In addition, the concentration of $\mathrm{H}_{2} \mathrm{~S}$ kept an upward trend as the exploitation time is relatively short in extended test area. There is no obvious pattern in the change of $\mathrm{H}_{2} \mathrm{~S}$ levels with time in the pilot test area. However, the time of steam drive controls the production of $\mathrm{H}_{2} \mathrm{~S}$ to some extent.

\section{Main influencing factors on $\mathrm{H}_{2} \mathrm{~S}$ concentration}

The concentration of $\mathrm{H}_{2} \mathrm{~S}$ in well gases varies significantly in the same area or under the similar reservoir conditions. Besides the geological conditions or geological backgrounds, the TSR reaction is probably the most important factor for the difference of $\mathrm{H}_{2} \mathrm{~S}$ concentration. Generally speaking, the TSR reaction is more likely to happen with an increase of depth and temperature. In addition, the amount of $\mathrm{SO}_{4}{ }_{4}^{2-}$ in the formation water is also an important influencing factor for the TSR reaction. If the $\mathrm{SO}_{4}{ }^{2-}$ levels drop substantially, the TSR reaction will stop.

Fig. 3 shows that the formation water collected in Qi 40 block is rich in $\mathrm{SO}_{4}{ }^{2-}$, which offers a source of reagent for TSR reaction and the concentration of $\mathrm{SO}_{4}{ }^{2-}$ mostly reduced after the thermal reaction. The reason is probably that TSR reaction has, in many cases, consumed most of the $\mathrm{SO}_{4}^{2-}$.

In addition, both the heating level of the reservoir and the duration of its high temperature affect the generation of $\mathrm{H}_{2} \mathrm{~S}$ gas. Usually, the content of $\mathrm{H}_{2} \mathrm{~S}$ gas becomes higher and higher with increasing reservoir heating time, indicating that the TSR reaction plays an important role in the generation of $\mathrm{H}_{2} \mathrm{~S}$. 


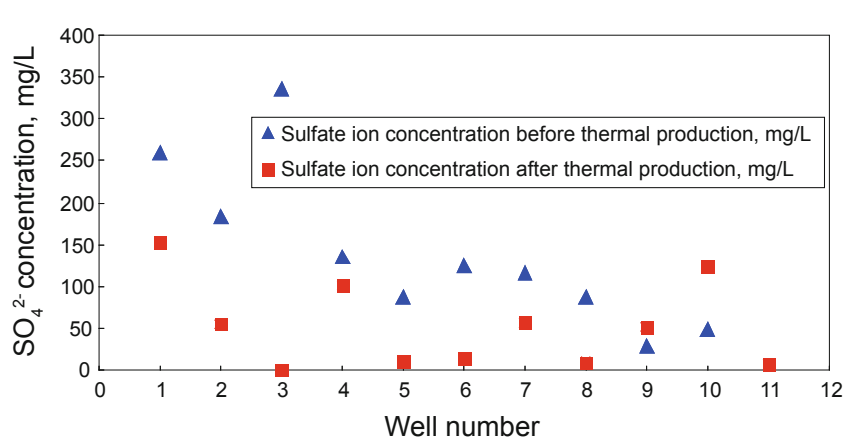

Fig. 3 Change of $\mathrm{SO}_{4}^{2-}$ in the formation water before and after thermal production for the Qi 40 block

\section{Distribution of $\mathrm{H}_{2} \mathrm{~S}$}

Considering the $\mathrm{H}_{2} \mathrm{~S}$ formation conditions and its control factors, $\mathrm{H}_{2} \mathrm{~S}$ will be generated in most oil wells in heavy oil thermal recovery areas and become a serious problem for safety and environmental protection if there are no countermeasures taken. In the thermal recovery region and in the absence of naturally occurring $\mathrm{SO}_{4}{ }^{2-}$ in the formation water, if no chemical reagents with $\mathrm{SO}_{4}{ }^{2-}$ were injected into the formation water, the TSR reaction would not take place. Hence, there will be little $\mathrm{H}_{2} \mathrm{~S}$ generated. $\mathrm{H}_{2} \mathrm{~S}$ from the thermal decomposition of crude oil is quite low, and will stop generating when the thermal decomposition of sulfocompound (TDS) in crude oil is finished. But the content of $\mathrm{H}_{2} \mathrm{~S}$ gas will increase if there is no measure to take in both the pilot areas and the expanded pilot areas. Taking the Qi 40 block for example, the pilot area with high $\mathrm{H}_{2} \mathrm{~S}$ content have low $\mathrm{SO}_{4}{ }^{2-}$ content because $\mathrm{SO}_{4}{ }^{2-}$ has been consumed by the TSR reaction, but the $\mathrm{SO}_{4}^{2-}$ content is still high in the peripherals of the pilot area, the $\mathrm{H}_{2} \mathrm{~S}$ content in the peripheral area will probably increase in the near future.

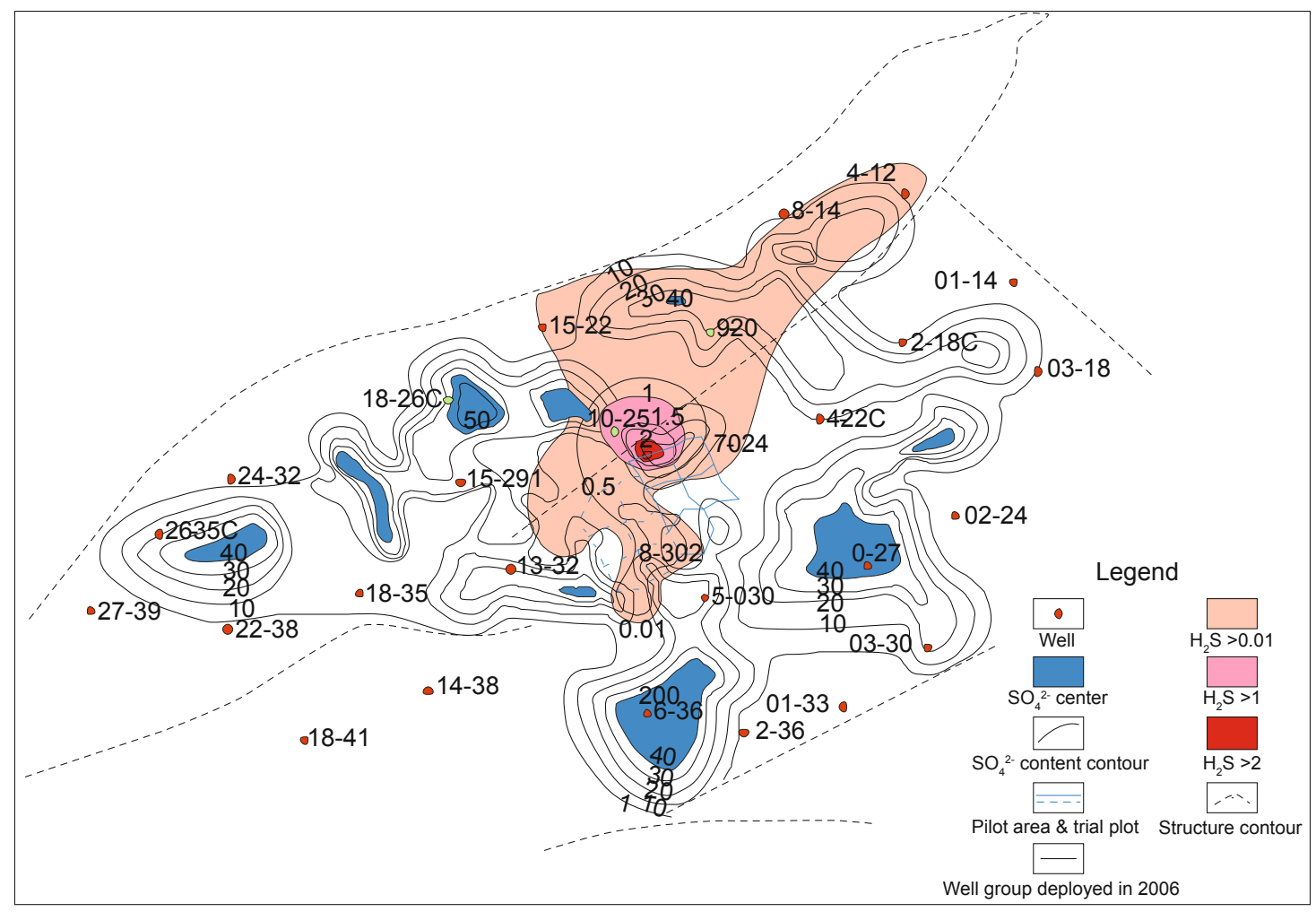

Fig. 4 Relationship between $\mathrm{SO}_{4}{ }^{2-}$ and $\mathrm{H}_{2} \mathrm{~S}$ distribution in the Qi 40 block

\section{Equipment damage from $\mathrm{H}_{2} \mathrm{~S}$}

Due to its strong chemical activity, $\mathrm{H}_{2} \mathrm{~S}$ is extremely corrosive to drill tools, gathering and transportation pipelines and so on. In addition, it can also cause "hydrogen brittleness". The corrosion will increase when $\mathrm{H}_{2} \mathrm{O}, \mathrm{CO}_{2}$ and $\mathrm{O}_{2}$ exist in the environment. Even low concentrations of $\mathrm{H}_{2} \mathrm{~S}$ can react with Fe to form a compact FeS film, which is mainly composed of $\mathrm{FeS}$ and $\mathrm{FeS}_{2}$. With increasing concentration of $\mathrm{H}_{2} \mathrm{~S}$, the $\mathrm{FeS}$ film becomes black loose layers or powders, that is, $\mathrm{Fe}+\mathrm{H}_{2} \mathrm{~S}$ $\rightarrow \mathrm{H}_{2}+\mathrm{FeS}$. Hydrogen brittleness and sulfide stress corrosion cracking are important mechanisms of metal corrosion, which is the one of the main reasons leading to major accidents. Corrosion perforation probably happens in plenty of casing and consequently underground pipelines would be corroded.
Sucker, oil pumps and many pipelines are scrapped due to corrosion each year. The maintenance and replacement of pipelines cost tens of millions of dollars because of corrosion. The content of $\mathrm{H}_{2} \mathrm{~S}$ is usually more than $500 \mathrm{mg} / \mathrm{L}$ in this equipment. Major accidents will happen, such as pipeline bursts, if no measures are taken to control the high levels of $\mathrm{H}_{2} \mathrm{~S}$.

\section{Harm prevention measures from $\mathrm{H}_{2} \mathrm{~S}$ in thermal recovery pilot areas of heavy oil in the Liaohe Oilfield}

\subsection{Periodic examination}

The components, structure of gaseous pollutants, 
especially $\mathrm{H}_{2} \mathrm{~S}$ must be monitored in the thermal recovery pilot areas of heavy oil. A unified, well-founded monitoring system for the main facilities should be developed in the heavy oil thermal recovery. The system should be able to monitor and identify if there is $\mathrm{H}_{2} \mathrm{~S}$ in the wellhead, oil, water tanks, purification tank, and other facilities or not. In addition, the monitoring system could make clear the quantitative relationship between $\mathrm{H}_{2} \mathrm{~S}$ emissions in the thermal recovery of heavy oil and the technologic process and meteorological parameters. All these measures are taken for preventing serious personnel injury and equipment damage due to high content of $\mathrm{H}_{2} \mathrm{~S}$.

\subsection{Making people aware of the harm of $\mathrm{H}_{2} \mathrm{~S}$ gas}

Much more should be done to make people to realize the risk and harm of $\mathrm{H}_{2} \mathrm{~S}$. Meanwhile, the warning signs and danger signs of $\mathrm{H}_{2} \mathrm{~S}$ should be pasted in the places where $\mathrm{H}_{2} \mathrm{~S}$ is usually generated at dangerous levels.

\subsection{Removing $\mathrm{H}_{2} \mathrm{~S}$ by absorption}

Plenty of liquids can be used as absorbents for $\mathrm{H}_{2} \mathrm{~S}$, such as neovaricaine, tripotassium phosphate, and sodium salt. Neovaricaine is the most efficient absorbent because of its high absorption rate, low freezing temperature and flexible equipment requirements. Each aqueous solution of monoethanolamine, diethanolamine and triethanolamine can also be used to remove $\mathrm{H}_{2} \mathrm{~S}$.

\subsection{Proper measures for protecting pipeline materials}

The use of nickel-phosphorous plating technology in pipeline materials is one preferred measure to protect the pipelines in the heavy oil thermal recovery. It can prevent or delay pipeline corrosion during the heavy oil thermal recovery process. The corrosion rate could be reduced by $50 \%$ to $70 \%$, which means that the working life of pipelines could be extended up to two or three times. In addition, pulse vacuum nitriding coating technology of tubes to resist corrosion is a useful chemical surface treatment technology. After the chemical surface treatment, the surface corrosion resistance of the pipelines could be greatly reduced as a dense white layer of corrosion resistance formed on the entire surface, without reducing the original mechanical properties.

\section{Treatment measures for $\mathrm{H}_{2} \mathrm{~S}$ in thermal recovery pilot areas of heavy oil in the Liaohe Oilfield}

\subsection{The present disposal method}

In the Huanxiling oil production plant of the Qi 40 pilot areas, measures for $\mathrm{H}_{2} \mathrm{~S}$ disposal are mainly venting at high altitude and control of casing pressure. Control of casing pressure can reduce emission of $\mathrm{H}_{2} \mathrm{~S}$, but it has a great influence on oil production. Oil pumps may suffer from gas locking when the casing gas gets into the pump, so it will affect the oil production. The Liaohe Oilfields have conducted casing control tests for the Qi 40-9-027 and 40-9028 wells, and found that the daily oil production of Qi 40-
9-028 well dropped from $12 \mathrm{~m}^{3}$ to $4 \mathrm{~m}^{3}$ after casing pressure control. The daily oil production of the Qi 40-9-027 well is still $4 \mathrm{~m}^{3}$, so the influence is small for Qi 40-9-027 well. $\mathrm{H}_{2} \mathrm{~S}$ was not removed after casing control, but ran into the system. This would result in the high concentration of $\mathrm{H}_{2} \mathrm{~S}$ in the transportation system.

At present, venting at high altitude is a good way for disposal $\mathrm{H}_{2} \mathrm{~S}$, but once the Qi 40 block comes into the stream drive stage, a large-amount of $\mathrm{H}_{2} \mathrm{~S}$ would be formed. Although the air can dilute the $\mathrm{H}_{2} \mathrm{~S}, \mathrm{H}_{2} \mathrm{~S}$ concentration on the ground will still exceed the limit as the density of $\mathrm{H}_{2} \mathrm{~S}$ is higher than air. Therefore, this method would not solve the problem.

\subsection{Restraining the generation of $\mathrm{H}_{2} \mathrm{~S}$}

It is known that $\mathrm{H}_{2} \mathrm{~S}$ is generated mainly from the thermal decomposition of sulfocompounds (TDS) within oil and from the TSR reaction. $\mathrm{H}_{2} \mathrm{~S}$ formed by TDS is much less, and sulfur compounds are used up after a long period of thermal recovery. So TDS plays less dominant role after a period of thermal recovery. TSR is mainly controlled by temperature and $\mathrm{SO}_{4}{ }^{2-}$ content. The temperature cannot be changed, so we could take measures to reduce $\mathrm{SO}_{4}{ }^{2-}$ content, for example, by not injecting $\mathrm{SO}_{4}{ }^{2-}$ bearing chemical reagents, thus, TSR reaction will be stopped or diminished due to lack of reactants, and the generation of $\mathrm{H}_{2} \mathrm{~S}$ will be stopped. Therefore, the key step for restraining the generation of $\mathrm{H}_{2} \mathrm{~S}$ is to control injection of $\mathrm{SO}_{4}{ }^{2-}$ bearing compounds.

\subsection{Not using sulfur compounds with thermal instability}

Before and after the steam drive, foaming agents, demulsifiers and other materials with sulfate ions or sulfonic acid ions have been injected into the reservoirs, some of which may be thermally unstable. So thermal decomposition can occur during the thermal recovery process and produce $\mathrm{H}_{2} \mathrm{~S}$. In spite of the distribution of $\mathrm{H}_{2} \mathrm{~S}$ being limited, it is very difficult to predict the distribution area of $\mathrm{H}_{2} \mathrm{~S}$. Also, it is difficult to predict the change of content of $\mathrm{H}_{2} \mathrm{~S}$. Therefore, the thermal stability performance of the reagents should be examined first before they are injected into the reservoir.

\subsection{In-situ burning of $\mathrm{H}_{2} \mathrm{~S}$}

$\mathrm{H}_{2} \mathrm{~S}$ is a combustible gas. In-situ burning of $\mathrm{H}_{2} \mathrm{~S}$ will reduce its harm. However, in the casing tube of Qi 40 block, the content of hydrocarbons is low, while the content of carbon dioxide is about $80 \%-95 \%$. Only a few wells have a low content (about $20 \%$ ) of carbon dioxide in the casing tube. Therefore, most of the oil well casing gas cannot be combusted directly. It needs to add natural gas for burning $\mathrm{H}_{2} \mathrm{~S}$. The reaction is: $2 \mathrm{H}_{2} \mathrm{~S}+3 \mathrm{O}_{2} \rightarrow 2 \mathrm{H}_{2} \mathrm{O}+2 \mathrm{SO}_{2}$. It would be better to use a chimney in this method as it can cause gas pressure different, which is helpful for burning. In addition, the combustion products can be diffused high in the air, and the harm is small. This method has the advantage of simple construction, small and flexible transformation process and low investment. It can be used not only for the single well but also for a platform or the oil wells nearby. For the Qi 40 
block, the processes in the whole block can be completely transformed in 2 to 3 weeks. The limitation of this method is that $\mathrm{SO}_{2}$ generated in the process is harmful to the environment. In addition, the contents of hydrocarbons and carbon dioxide often fluctuate, so the natural gas to casing gas ratio is not easy to control, that is, if not enough natural gas is added, the combustion of the mixed gas will be incomplete. While if too much natural gas is added, energy and gas is wasted. However, this method can be used for combustible gas, to avoid loss of gas in the casing tube. For the gas that cannot be ignited, desulfurating agent adsorption technology can be used instead.

\subsection{Centralized disposal in a desulfurization plant}

In the heavy oil areas, the generation of $\mathrm{H}_{2} \mathrm{~S}$ cannot be controlled when using plenty of steam. A small-scale desulfurization plant for disposal of $\mathrm{H}_{2} \mathrm{~S}$ should be established in a suitable location. The desulfurization technology is relatively mature in China, for either dry or wet desulfurization technology. In addition, there is a lot of experience in the manufacture, use, and maintenance of such equipment in China.

\section{Conclusions}

Large amounts of toxic $\mathrm{H}_{2} \mathrm{~S}$ gas is generated during the process of thermal recovery of heavy oil in the Liaohe Oilfield, China. The gas is mainly formed by the thermochemical sulfate reduction (TSR) occurring in the oil reservoirs. Also, it can be formed by the thermal decomposition of sulfocompound (TDS) in crude oil. The generation and distribution of $\mathrm{H}_{2} \mathrm{~S}$ gas are controlled by the time and style of exploitation, temperature in the thermal recovery and the injected chemical reagents.

$\mathrm{SO}_{4}{ }^{2-}$ is the necessary material for TSR reaction. The supply rate of $\mathrm{SO}_{4}{ }^{2-}\left(\mathrm{SO}_{4}{ }^{2-}\right.$ content in the formation water) is the most influencing factor for the rate of TSR reaction. The content of $\mathrm{SO}_{4}{ }^{2-}$ of the boiled water injected into the reservoir is high, which provided $\mathrm{SO}_{4}{ }^{2-}$ source for the TSR reaction. It is also the reason that content of $\mathrm{H}_{2} \mathrm{~S}$ is relatively high in the pilot areas.

In the process of $\mathrm{H}_{2} \mathrm{~S}$ prevention, periodic and effective monitoring should be undertaken in the heavy oil thermal recovery pilot areas. In addition, $\mathrm{H}_{2} \mathrm{~S}$ gas absorbents and corrosion resistant pipeline material should also be used. We should make every effort to control the generation of $\mathrm{H}_{2} \mathrm{~S}$ in the heavy oil recovery areas in the beginning, such as cutting off the supply of sulfate to the TSR reaction. The method of burning in the well field or adsorption by desulfurizer could also be considered for the disposal of $\mathrm{H}_{2} \mathrm{~S}$ gas.

In conclusion, the distribution area and concentration of $\mathrm{H}_{2} \mathrm{~S}$ gradually increases along with extension of heavy oil thermal recovery area. As a result, the potential safety hazard resulted from $\mathrm{H}_{2} \mathrm{~S}$ becomes larger and larger. It will result in higher risk for exploitation of heavy oil. Also, it becomes challenging for the health of workers and protection of equipment. Therefore, it will produce good social benefits such as stable production, better occupational health levels, protection of equipment from corrosion and environmental protection if the dynamic distribution in situ of $\mathrm{H}_{2} \mathrm{~S}$ is well researched and measures to prevent the formation of $\mathrm{H}_{2} \mathrm{~S}$ are taken.

\section{Acknowledgements}

The research was supported by the National Natural Science Foundation of China (Grant No. 40602016; 40773032) and the National Basic Research Program of China (Contract No. 2007CB209500).

\section{References}

Aplin A C and Coleman M L. Sour gas and water chemistry of the Birdport Sands reservoir, Wytch Farm, UK. In: England W A (Editor), The Geochemistry of Reservoirs. Geological Society of London Special Publication. 1995. 86: 303-314

Dai J X, Hu J Y and Jia C Z. Suggestions for scientifically and safely exploring and developing high $\mathrm{H}_{2} \mathrm{~S}$ gas fields. Petroleum Exploration and Development. 2004. 31(2): 1-5 (in Chinese)

Krouse H R, Viau C A, Eliuk L S, et al. Chemical and isotopic evidence of thermochemical sulfate reduction by light hydrocarbon gases in deep carbonate reservoirs. Nature. 1988. 333(2): 415-419

Lamoureux-Var V and Lorant $\mathrm{F}$. $\mathrm{H}_{2} \mathrm{~S}$ artificial formation as a result of steam injection for EOR: A compositional kinetic approach. SPE. 2005. 97810

Machel H G. Bacterial and thermochemical sulfate reduction in diagenetic settings-old and new insights. Sedimentary Geology. 2001. 140: 143-175

Machel H G, Krouse H R and Sassen R. Products and distinguishing criteria of bacterial and thermochemical sulfate reduction. Applied Geochemistry. 1995. 10(4): 373-389

Mougin P, Lamoureux-Var V, Bariteau A and Huc A Y. Thermodynamic of thermochemical sulfate reduction. Journal of Petroleum Science and Engineering. 2007. 58: 413-427

Orr W L. Geologic and geochemical controls on the distribution of hydrogen sulfide in natural gas. In: Campos R, Goni J. (Eds), Advances in Organic Geochemistry 1975, Madrid, Empressa Nacional Adaro de Investigaciones Mineras. 1977. 571-597

Wilhelm H E L. Status of the steam drive pilot in the Georgsdorf field, Federal Republic of Germany. SPE. 1981. 8385: 173-180

Worden R H, Smalley P C and Oxtoby N H. Gas souring by thermochemical sulfate reduction at $140{ }^{\circ} \mathrm{C}$. Bulletin of American Association of Petroleum Geologists. 1995. 79: 854-863

Zhang S C, Zhu G Y, Liang Y B, et al. Geochemical characteristics of the Zhaolanzhuang sour gas accumulation and thermochemical sulfate reduction in the Jixian Sag of Bohai Bay Basin. Organic Geochemistry. 2005. 36(12): 1717-1730

Zhu G Y, Zhang S C, Liang Y B and Li J. Discussion on origins of the high- $\mathrm{H}_{2} \mathrm{~S}$-bearing natural gas in China. Acta Geologica Sinica. 2005a. 79(5): 697-708

Zhu G Y, Zhang S C, Y B. Dai J X and Li J. Isotopic evidence of TSR origin for natural gas bearing high $\mathrm{H}_{2} \mathrm{~S}$ contents within the Feixianguan Formation of the Northeastern Sichuan Basin, southwestern China. Science in China. 2005b. 48(11): 1037-1046

Zhu G Y, Zhang S C and Liang Y B. The controlling factors and distribution prediction of $\mathrm{H}_{2} \mathrm{~S}$ formation in marine carbonate gas reservoirs, China. Chinese Science Bulletin. 2007. 52 (Supplement I): $150-163$

Zhu G Y, Zhang S C and Liang Y B. The origin and distribution of hydrogen sulfide in the petroliferous basins, China. Acta Geological Sinica. 2009. 83(6):1188-1201 